International Business Management 4 (4): 209-221, 2010

ISSN: $1993-5250$

(C) Medwell Journals, 2010

\title{
Technology and Service Quality in the Banking Industry: An Empirical Study of Various Factors in Electronic Banking Services
}

\author{
${ }^{1} \mathrm{~S}$.T. Akinyele and ${ }^{2} \mathrm{~K}$. Olorunleke \\ ${ }^{1}$ School of Business, Covenant University, OTA, Nigeria \\ ${ }^{2}$ Department of Business Administration, Ondo State University, Akungba
}

\begin{abstract}
Technology-based self service has greatly changed the way that service firms and consumers interact and are raising a host of research and practice issues relating to the delivery of e-service which has become increasingly important not only in determining the success or failure of electronic commerce but also in providing consumers with a superior experience with respect to the interactive flow of information. The purpose of this research study was to establish the relationship between technology and service quality in the banking industry in Nigeria. The research was carried out through a cross sectional survey design which questioned respondents one e-banking services. The population of study mainly constituted of customers of Oceanic bank within Lagos metropolis and its environs. The respondents of the study were customers of banks using e-banking services (internet banking, mobile banking and ATM). The sample in this study consisted of 120 respondents who are users of the e-banking services. The data collected was analyzed by use of frequency, percentage, means and correlation analysis. The findings revealed that secure services as the most important dimension, followed by convenient location of ATM, efficiency (not need to wait, ability to set up accounts so that the customer can perform transactions immediately, accurately of records, user friendly, ease of user, complaint satisfaction, accurate transactions and operation in $24 \mathrm{~h}$ ).
\end{abstract}

Key words: Technology-based self-service, customers, electronic commerce, service quality and banking industry, Nigeira

\section{INTRODUCTION}

Recent advances in technology have created a surge in technology-based self service (Dabholkar, 2000). Such developments are changing the way that service firms and consumers interact and are raising a host of research and practice issues relating to the delivery of e-service. E-service is becoming increasingly important not only in determining the success or failure of electronic commerce (Yang, 2001) but also in providing consumers with a superior experience with respect to the interactive flow of information. The financial system around the world has been facing a lot of changes. Mergers and acquisitions, deregulation, increased competition, changing information systems and technology and human resources with different skills are just a few forces that are influencing the banking business.

Technology is one leading driving force now-a-days in different businesses (Lake and Hickey, 2002). It is therefore important to research the investments in technology and their impact in the bank business (Lewis and Mitchell, 1994; Sethi and King, 1994). It is particularly important to assess how technology is reducing the labour service and processing cost, increasing service levels and improving the productivity and competitiveness of the Nigerian financial sector.

Technology is made up of discoveries in sciences product development and improvement in machinery, process and automation and information technology. It also includes a combination of knowledge, information and ideas. The literature provides an extensive account of the relationships between service quality, customer satisfaction and financial performance where face to face interaction between customer and employee is the only focus.

Recently however, technology had remarkable influence on the growth of service delivery options (Dabholkar and Bagozzi, 2002). Dabholkar (2000) claims that when the customer is in direct contact with the technology there is greater control such as with internet banking.

However, if there is an absence of direct contact, such as with telephone banking, it is assumed that there is less control perceived by the customer during this transaction. Bateson (1985) has conducted a number of studies on the need for consumers to have control during

Corresponding Author: S.T. Akinyele, School of Business, Covenant University, OTA, Nigeria 
service encounters. When a consumer freely chooses to use technology as a form of service delivery the impact is high in terms of quality attributes. Some of the quality factors that are highly important to consumers are efficiency and speed (Bateson 2000).

This concept is supported by (Weatherall, 1984) who state that consumers are thought to have a positive perception of technology will deliver faster and more efficient service than that of the employee. Gummeson (1991) also stresses that reliability and user friendliness are important factors in the evaluation of technology- based services.

Service quality can be seen as the extent to which a service meets customer's needs and expectations (Lewis and Mitchell, 1994). Service quality can thus be defined as the difference between customer expectations of service and perceived service. If expectations are greater than performance then perceived quality is less than satisfactory and hence customer dissatisfaction occurs (Parasuraman et al., 1995).

Service quality has been recognized as having the potential to deliver strategic benefits, such as improved customer retention rates, whilst also enhancing operational efficiency and profitability (Cronin 2003; Rust and Lemon, 2001; Zeithaml, 2000a, b). Oliveira (2002) suggest that e-service quality is amongst a firm's competitive capabilities that lead to business performance, Pyun saw issues in implementing service technology and e-services as critical in service operations and Al-Hawari and Tony (2006) describes that service quality impacts on customer satisfaction which in turn affects the financial performance of banks.

Technology and service quality: The proliferation of and rapid advances in technology-based systems, especially those related to the internet are leading to fundamental changes in how companies interact with customers (Chowdhary and Prakash, 2007; Bauer et al., 2005; Akinyele and Akinyele, 2008). This trend is well established in the service industry, where service providers are increasingly urged to invest in technology to better secure their future in the electronic age (Zhang and Prybutok, 2005; Bauer et al., 2005).

Today's winners are those who overcome consumer cynicism by exceeding expectation and going beyond the point of encounter. These firms are successful because they have invested for the long term through recognizing that service fulfillment not only promotes growth of their customer base but retains customer loyalty (Lake and Hickey, 2002). The challenging business environment in the financial service market has also resulted in more pressure on banks to develop and utilize alternative delivery channels with a view to attracting more customers, improving customers' perceptions and encouraging loyalty (Bauer et al., 2005; Lee and Lin, 1996; Parasuraman et al., 1995).

Among the more recent delivery channels introduced is electronic banking. In its simplest form, electronic banking means the provision of information about the bank and its products via a page on the internet. Davis et al. (1989) however, defines the term as the provision of information and/or services by a bank to its customers via computer, telephone or television.

A more developed service in Daniel (1999)'s view is one that provides the customers with the opportunity to gain access to their accounts execute transactions or buy products online or via other electronic means such as television or Automated Teller Machines (ATM).

The installation of customer friendly technology (such as menu driven automated teller machines, telephone and internet banking services) as a means of delivering traditional banking services has become common place in recent years as a way of maintaining customer loyalty and increasing market share. Traditional brick and mortar banks are using technology to meet the competitive challenge posed by online banks, as well as a method of reducing the cost of producing services that were once delivered exclusively by bank personnel (Joseph and Beatriz, 1997; Akinyele, 2007).

Managers in virtually all industries understand that providing quality customer service is a very strategic component in firm profitability. The importance of service delivery and its impact on improving satisfaction and retention of customers, improving sales and market share and improving corporate image cannot be overstated (Lewis and Mitchell, 1994). As with most other service providers, banks have moved quickly to invest in technology as a way of controlling costs, attracting new customers and meeting the convenience and technical innovation expectations of their existing customers (Barnes and Vidgen, 2000; Akinyele, 2007).

Service quality differs from material goods quality. Bateson and Hoffman (1997) defined services as deeds, efforts or performance whilst Regan (1963) saw services as activities, benefits or satisfactions offered for sale or provided in connection with the sale of goods. Eservice is deeds, efforts or performances whose delivery is mediated by information technology (including the web, information kiosks and mobile devices). Such eservice includes the service element of e-retailing, customer support and service and service delivery (Bateson, 1985; Bitner, 2000; Zhang and Prybutok, 2005). Services by definition are intangible and easily duplicated. They can be divided into high-touch or 
high-tech services. High- touch services are mostly dependent on people in the service process producing the service whereas high-tech services are predominantly based on the use of automated systems, information technology and other types of physical resources. However, one should always remember that high-touch also includes physical resources and technology-based systems that have to be managed and integrated into the service process in a customer-oriented fashion (Carman, 1990; Gronroos, 2001; Bitner, 2001). Thus, in this study, technology banking services include both high-tech and high-touch services.

For example, high-tech services include internet/ telephone/Short Messaging Services (SMS), ATM machines whereas high-touch services consist of instructions and personnel assistance in using the services. Quality is differentiable and seen from the expectations of customers. Hence, it is necessary to identify and prioritize expectations for service and incorporate these expectations into a process for improving service (Ojunga, 2005; Goodman et al., 1986; Cox and Dale, 2001). Implementing and evaluating service quality is a very complex process. Two aspects need to be taken into consideration when evaluating service quality: content and delivery (Zeithaml and Bitner, 1996; Dabholkar, 2000; Dabholkar and Bagozzi, 2002). Customers may be in the best position to evaluate the quality of delivery while the service providers are the best judges of the content of the message.

Though, there are a number of different aspects of services involved, this study focuses on only one, the perceptions of technology users as to the quality of the services.

Quality has been defined from different perspectives and orientations, according to the person making the definition, the measures applied and the context within which it is considered (Tapiero, 1996; Doyle and Melanson, 2001; Distri, 2003). It has been defined as excellence value (Peter and Waterman, 1995; Fengenbaum, 1995; Joseph and Beatrize, 1997), fitness for use (Juran and Gryana, 1988; Hawkins, 2001), conformance to requirement (Crosby, 1979) and meeting and/or exceeding customers expectations (Parasuraman et al., 1995; Lang and Colgate, 2003). More often than not customers demand quality experience and their resultant behaviour is replicated in terms of an attitude towards consumption behaviour which has led researchers and analysts to regard quality as a single most important factor for long term success and survival.

Because of this (Martilia and James, 1977; Lehtinen and Lehtinen, 1982; Lloyd-Walker and Cheung, 1998) asserts that quality aims at the needs of the customer, present and future. As perceived service quality portrays a general, overall appraisal of service i.e., a global value judgment on the superiority of the overall service, it is viewed as similar to attitude.

Prescriptions of service quality could occur at multiple levels in an organization e.g. with the core services, physical environment and interaction with service providers (Lovelock, 1991) on the other hand customer's overall satisfaction with the service organization is based on a function of all the encounters or experiences of the customers with that of the organization.

Similar to service quality, customer satisfaction can occur at multiple levels of an organization. For example with the contact person, satisfaction with the core service and satisfaction with the organization as a whole. Service quality is a concept that has aroused considerable interest in the research literature because of the difficulties in both the defining it and measuring it with no overall consensus emerging on either (Moon and Free, 2000; Yen, 2005; Zairi, 2003).

There are a number of different other definitions as to what is meant by service quality. One that is commonly used defines service quality as the extent to which a service meets customer's needs and expectations (Lewis and Mitchell, 1994). Service quality can thus be defined as the difference between customer expectations of service and perceived service. If expectations are greater than performance, then perceived quality is less than satisfaction and hence customer dissatisfaction occurs (Parasuraman et al., 1995).

Degree of intangibility has been proposed as a means of distinguishing between products and services (Martilia and James, 1977; Mols 1998; Walker, 2002; Walter, 1994; Zeitham1, 2000a, b) highlight the fact that degree of tangibility has implications for ease of service or product quality evaluation. Onkvisit and Shaw (1991) and Akinyele (2007) feel, however that the significance of intangibility is over emphasized and that the service provider's offer is their productive capacity. As services are produced and consumed simultaneously, customers are present and may take part in the delivery process.

They may therefore, affect or shape the performance and quality of the service, in some cases causing disruption and increased waiting time and consequently lower customer satisfaction (Zeithaml and Bitner, 1996; Ojunga, 2005). Doyle and Melanson (2001) suggests that connections between the employee and customer can be made through physical, psychological or electronic means but some sort of interactivity must be present if a quality service that sustains long term customer satisfaction is to be the result. Quality in the service operation is actually 
created at the moment of truth (Carman, 1990; Parasuraman et al., 1998; Parasuraman and Colby, 2001; Gronroos, 2001) refers to this as the moment of opportunity where value can be added to the perceived service quality.

Once the customer has lef however, a new moment of truth must be created, such as a service recovery (Lang and Colgate, 2003) to connect a previously created problem. Bitner (2001) and Turban et al. (2002) goes further to say that in services the offering and the employee are inseparable. Banks have largely implemented service delivery technology as a way of augmenting the services traditionally provided by bank personnel. Implementation results both from the need to reduce the cost of delivering service primarily through personnel and the corresponding need to meet the challenge posed by technologically innovative competitors (Zhang, 2000; Hawkins, 2001; Nielsen, 2002).

Changes in the banking industry such as those resulting from deregulation, rapid global networking and the rise in personal wealth have thus made the implementation of sophisticated delivery systems (e.g., online and telephone banking, remote site automated teller machines etc.) a strategic necessity in many case (Ennew, 1993; Zhang, 2000).

Dabholkar (1994) discusses how technology-based services have made new service delivery options available to organizations, making customers participation more widely possible. Customers use touch screen kiosks to order take-away food whilst banks have widely distributed automatic teller machines to withdraw, transfer funds, make deposits into accounts or conduct any other transactions e.g., balance inquiry. The difficulty with technology in services is that it tends to make the moment of truth a mechanical experience, lacking in emotion. For the customer to remain satisfied, everyone in the organization has to take the responsibility for helping the customer (Bitner, 2001). Berry (1995) talks of competing for talent in employees, setting high standards and sticking to those standards whilst Parasuraman and Colby (2001) highlight the importance of bringing purpose and meaning to employees, jobs and of empowering them without the fear of reprisal.

Additionally, changing the organizational culture to encourage employees to adopt the right first time philosophy is essential (Oakland, 2000). Whilst training is of importance, it is also costly and careful consideration must be given as to how it can help improve process management, as well as meeting needs and expectations (Oakland, 2000). Technology can help people fulfil their requirements more efficiently but a company is still only as good as its people (Gronroos, 2000). The difficulty comes in identifying individuals motivating factors and harnessing them in the right way. No matter which service delivery channel is used, the service provider/service user relationship must be nurtured at all costs (Lioyd and Cheung, 1998).

The more customers go online to fulfil their service needs themselves, the more scalable and cost effective the business model (Mols, 1998). This association between service quality and business performance has driven interest in e-service, online service and internet retailing. This interest has been further fuelled by evidence of poor e-service quality in some contexts (Bateson, 1985; Dabholkar, 2000; Zeithaml, 2000a, b).

Zeithaml (2000a, b) identifies the need for businesses to focus on the e-service in their e-business and to understand the importance of e-service quality as a differentiating strategy. Businesses also need to recognize that the web experience presents the brand positioning to online customers (Oliveira, 2002) and may be an important elements in the establishment of trust and relationships with customers (Turban et al., 2002; Yang, 2001; Zeithaml, 2000b; Peter and Waterman, 1995).

Exploring e-servqual: The importance of measuring and monitoring e-ervice quality has been recognized by managers and academics (Lang and Colgate, 2003). Service quality is a key determinant in differentiating service offers and building competitive advantage (Igbal, 2003; Gronroos, 2001; Bauer et al., 2005). In addition a rich seam of academic research on e- service quality has early research by Zeithaml (2000a) and Rust and Lemon (2001). Such research is useful in seeking to surface dimensions of the e-service experience from the customer experience and evaluation perspective.

There is growing recognition of the considerable variability in the outcomes of these studies on service quality in terms of the dimensions that are being surfaced (Walker, 2002; Kim, 2006). There are no well accepted conceptual definitions and models of service quality and its measurement (Sethi and King, 1994). Technology readiness or stage of e-service adoption may impact on the service experience and perceptions of e-service quality (Zeithaml, 2000a, b; Mols, 1998). Nielsen (2002) suggest that the dynamics of service attributes are dependent on the stage of the customer adoption curve at which the customer has arrived and (Yen, 2005) articulates the same theme more specifically when she suggests that the importance of attributes of user satisfaction with internet-based self service technology is dependent on technology readiness. The complementary body of work on the antecedents to e-service adoption 
also suggests caution in interpreting customer evaluations of e-service, when their experience of e-service is much more limited than experience of p-service (Dabholkar, 2000; Bitner, 2001; Igbal, 2003; Yang, 2001). For example, Yang (2001) note the differences in the dimensions of e-service quality between purchasers and non-purchasers whilst (Igbal, 2003) note that consumer usage frequency is a factor in e- service evaluation.

Bitner (2001) suggest that customers need to understand what is expected of them and to perceive benefits from the change in behavior associated with adoption. Sethi and King (1994) in a review of service quality models suggests that customer's expectations towards particular services are in a constant state of evolution and are influenced by the user's number of encounters and the competitive environment.

Yang and Fang (2004) suggest a differentiation between dimensions that are satisfiers and dissatisfiers. Some authors are starting to differentiate between dimensions for core service delivery and recovery services (Parasuraman et al., 1995) whilst others depart from the notion of dimensions altogether and base their analysis on categories of service delivery (Bauer et al., 2005; Kim, 2006) seek to operationalize and extend (Parasuraman et al., 1995) in order to use them for content analys is and evaluation and benchmarking of websites in the apparel retailing sector.

Technology in the banking industry: Technological developments have removed repetitive, time consuming tasks, reduced human error and extended access to banking related facilities. Technology also provides customer information that it would be much more expensive to provide on a person to person basis. Telephone banking facilities allow non cash transactions to be carried out which would have required a visit to a branch earlier (Zairi, 2003). Similarly, internet banking allows customers to perform tasks at a time and in a place convenient to them. Dabholkar (2000) suggests that direct contact with such technology also gives customers a feeling of greater control. Goodman et al. (1986) is of the opinion that technology was introduced in banks originally to reduce costs but that by dividing front and back office operations, technology can be targeted to enhance different functions.

The dilemma still remains, however, as to how to maintain a satisfactory number of face to face interactions with the customers. Oliveira (2002) identified five characteristics or attributes of innovations that affect the rate at which innovations are adopted (and ultimately their usage patterns): their relative advantage, compatibility, complexity, divisibility and communicability. Additional characteristics were later added; perceived risk (Oakland, 2000) and financial and social cost (Zeithaml, 2000a).

In the categorization of services in technologybased service delivery options (Dabholkar, 2000) suggests there are a number of relevant classifications that will apply to industries employing technology based service. That is, person to person, where the employee uses the technology or consumer to technology, such as the use of ATM. The next categorization looks at where the service is delivered. Either on the service firm's or at a neutral site such as an ATM model located at an airport.

The final categorization looks at the contact the customer has with the service operation, either direct or indirect such as in the case of telephone banking. Dabholkar (2000) stipulates that there should be flexibility in the design of the technology to allow customers to make changes during the transaction and make available a customer service advice if required with minimum waiting. This also raises the design issue of sufficient menu options for ATM/telephone and internet bankers.

In most cases, the transaction occurs in a neutral location and the availability of an employee may not always be feasible since these facilities often operate $24 \mathrm{~h}$ a day, 7 days a week.

Continuous improvements in the information technology have enabled banks to provide their services in a more direct manner to adjust their products better to the clinteles needs. Although, banking has always been an information business, until now information technology was mainly used to automate administrative processes. The shift from automating ti informing using information and its flow to inform managers provides opportunities to track a customer's behavior and respond at the right time by making effective use of these opportunities, banks are able to transfer a great deal of transactions from branch offices to a call-centre (Kim, 2006). Accessibility has been extended through technological developments as well as the introduction of new service delivery methods that allows consumers to do business with service firms from the home and office.

Electronic banking is an umbrella term for the process by which a customer may perform banking transactions electronically without visiting a brick and mortar institution. The following terms all refer to one form or another of electronic banking: Personal Computer (PC) banking, internet banking, virtual banking, online banking, home banking, remote electronic banking and phone banking. PC banking and internet ot online banking are the most frequently used designations. It should be noted, however that the terms used to describe the 
various types of electronic banking are often used interchangeably (Igbal, 2003). Internet banking is predicted to transform and revolutionalized traditional banking industry (Mols, 2000; Daniel, 1999; Parasuraman et al., 1995). Banking services are easily digitalized and automated and thus, form an operational perspective, lend themselves to the internet (Onkvisit and Shaw, 1991; Daniel, 1999). The potential competitive advantage of the internet for banks lies in the areas of cost reduction and satisfaction of consumer needs.

According to Hawkin (2001) m-commerce (mobile commerce) that included WAP has some features of mobile business include: ubiquity. Mobile technology enables the user to access information whenever they are assuming the user is within the cellular broadcast area, personalization. Due to the limited memory capacity of the mobile hardware, software enables a finer degree of sorting and categorization to meet the mobile users' needs, flexibility. The mobility of the hardware, e.g., cellular handsets permit the user to conduct transactions and/or receive information even when the user is engage in another activity such as traveling or working, dissemination, originators of information, for example local retailers, any use the wireless network of m-commerce to deliver specific information to some or all WAP users that come into the geographic region.

Automated Teller Machines (ATMs) are also known as electronic cash machine; an electronic machine that enables customers to withdraw study money or carry out other banking transactions on insertion of an encoded plastic card (MSA. Encarta). Automated Teller Machines (ATMs) are nothing new but not all cardholders make full use of all the facilities that ATMs offer. Due to ignorance or technophohia, many clients still opt for more cumbersome and costly methods of banking (Gronroos, 2000). Bank clients who hate waiting in long queues at the bank, prefer ATM banking. It offers the customer the convenience of being able to do must of their banking from a machine often situated outside the bank, so that they have access to their bank account $24 \mathrm{~h}$ a day.

Technology, an aspect of the design, means the process for transforming materials to finished products. In the public sector, the information constitutes the material and the public service the product. More broadly stated, to include the types of work done in the most public agencies, technology refers to the programme and procedure designed to respond to situations and process cases to achieve the results specified in the mandate of the agency. It does not refer to machines and equipment only but to the programmes and performance routines of the agency (Gummeson, 1991). Utilization of technology today, offers dramatic and enduring improvements in enhancing organizational performance (Boer, 2002; Carman, 1990; Davis et al., 1989; Mols, 2000; Roth and Menor, 2003).

Statement of the problem: When customers evaluate the quality of the service they receive from a banking institution they use different criteria which are likely to differ in their importance, usually some being more important than others. While several criteria are important only a few are most important. These determinant attributes are the ones that will define service quality from the consumer's perspective (Sethi and King, 1994).

However, many established models of service quality have tended to focus on expectations and marginalize the issue of importance. Thus for example, of the most widely used model to measure perceived service quality was developed by Parasuraman et al. $(1985,1995,1998)$. The banking industry has already been depicted (Parasuraman et al., 1998) as exhibiting little market orientation and fulfilling service with little regard to customer needs as well as including branches dissimilar in efficiency, long lines, limited time for customer servicing, transaction errors, excessive bureaucracy, security and network failures have been said to be the most frequent problems using banking services (Vandermerwe, 1993; Daniel, 1999). This highly lower customer's perception on the quality of service offered and hence reduces the bank's profitability and credibility.

In the current climate, competition in the banking industry is intense with new financial service providers emerging all the time. Quality of service is seen more than ever as a key differentiator in the marketplace. One question relates to whether automated, telephone and internet banking represent positive change and are delivering enhanced service quality.

There is then the further question as to who receives benefit from the use of IT-the customer, the employee or the bank? Whilst technology can save time and money and eliminate errors, thereby addressing certain issues associated with changing cultural and social trends, it can also minimize direct customer interaction and any associated service value to be gained (Smith, 1987, 1993; Bitner, 2001). According to Joseph et al. (1999), reliable and accurate banking services, customer services; personalized services and accurate records are some of the factors which are considered by the customers in their choice of a given type of service delivery channel.

Since the year 2000 , technology has increasingly been employed in the delivery of services in the Nigerian banking industry. The adoption of technology into service industries more so in banking is becoming a strong trend as service providers are now being urged by 
industry bodies to invest in technology. The small business segment (retail and corporate services) has not been an easy one for the main banks to target and a number of studies have highlighted imperfection in service provision and problems regarding service quality (Ennew, 1993; Bauer et al., 2005). Particularly problematic areas include knowledge and understanding, providing explanations for decisions, queuing, charges, collateral requirements, network failure and insecurity.

Due to this, customer satisfaction levels are at all time low, dragging the bank's image, credibility and staff morale down (Joseph and Beatriz, 1997; Schltze, 2003). A number of studies have been done on service quality delivery in the banking industry. These include relative importance of technology in service delivery in banking which concluded that technology provides a different type of value and the benefits to be gained are largely efficiency based. Mugambi (2006) also attest that researches have been done on areas of service excellence and customer satisfaction in the banking industry. However, there is no study in Nigeria that had looked at the relationship between technology and service quality in the Nigerian banking industry.

This study therefore, sought to investigate the relationship between technology and service quality in the Nigerian Banking industry. What is the relationship between technology and service quality? Which are the factors that lead to customer preference of different service delivery channels? The specific objectives were:

- To establish the relationship between technology and service quality in banking industry

- To determine the factors that lead to customer preference of different electronic banking channel

\section{MATERIALS AND METHODS}

The research was carried out through a crosssectional survey design which asked respondents on ebanking services. The design of the questionnaire was based on a multiple-item measurement scale (e-banking services). It looked into the relationship between technology and service quality in the Nigerian banking industry. This study is suitable when dealing with many members in a population where it is not possible to study all of them and hence calling for sampling in order to come up with a generalizations and inferences about the whole population. Similar studies that have successfully used this research design (Berry et al., 1994; Barnes and Vidgen, 2000; Moon and Free, 2000; Zeithaml, 2000b). The population of study was drawn from banks within Lagos and Ota, Nigeria. This mainly constituted of customers of banks within the central business district. The respondents of the study were customers of banks using e-banking services (internet banking, mobile banking and ATM). The target populations were headquarters and branches of various banks. The sample in this study consisted of respondents who were users of the e-banking services (internet banking, mobile banking and ATM).

A data for the study came from self-administered questionnaires which were distributed to 120 personal and corporate customers in Lagos and Ota and therefore, comprised of city dwellers because of time and resource limitation (Ontunya, 2006). Similar approach was adopted by Berry et al. (1994), Berry (1995) and Saunders (1994). The sample constituted of $77 \%$ of personal customers while $23 \%$ of the customer was derived from corporate customers. This enabled the researchers to get the mixed perceptions of the two groups in the usage of various electronic channels.

The study used primary data which was captured through semi-structured questionnaires. The questionnaire consisted of both closed and open ended questions and had three sections. Section one dealt with general information on the participants. Section two sought information on the relationship between technology and service quality in the banking sector. Section three sought information on the factors that lead to customer preference of different service delivery channels.

The questions were presented in the form of statements on a 1-5 Likert scale for respondents to score statements that describe the consumer's perceptions of electronic banking performance and the most important attributes of electronic banking service. The researchers captured the customers during peak hours i.e., lunch and evening hours. At this time, more financial transactions took place and therefore, there were high chances of capturing many customers. The researchers mainly used a mall intercept method to capture the respondents (out of every five customers in the queue, one was selected. To establish the relationship between technology and service quality in the Nigerian banking industry, frequency and percentage proportions of the statement describing the relationship were used. From the same scores, means were calculated to determine the perceived relationship. i.e., the strength of relationship. Correlation analysis was also used to establish the relationship between technology and service quality in the banking industry.

To determine the factors that lead to customer preference of different service delivery channels, the score of customer preference was cross tabulated to 
establish the degree of influence. From these scores, means and percentage proportions were used to rank the factors that influence the preference of different service delivery channels. Generally, there is no agreement on which format is most appropriate for measuring service quality. However for this particular study, using I/P grid more readily provided easy access for practitioners to the findings and suggestions for improvement. The factors to be tested included: reliable and accurate banking services, customer service, personalized services and accurate records.

\section{RESULTS AND DISCUSSION}

Data was collected from customers who use electronic banking in the banks (Oceanic bank plc). Consequently, the collected data was analyzed and interpreted in line with the aims of the study which include to establish the relationship between technology and service quality in banking industry and to determine the factors that lead to customer preference of different electronic banking channels. Of the 120 questionnaires distributed were returned giving a response rate of $62.5 \%$ which was considered satisfactory for subsequent analysis.

This analysis focused on relevant dimensions of service using the items involved. These were then examined in a more detail for purposes of comparison between themselves and across respondents. A model with four factors listed below may be adequate to represent the data for this particular sample of Nigerian banking customers, reliable and accurate banking services, customer service, personalized service and accurate records.

The Performance of Electronic Banking Channels with Respect to the Service Quality Dimensions. The respondents were asked the latest electronic banking service they have used. It was revealed that more customers have adopted ATM banking than mobile and internet banking. This implies that the banking customers are more familiar with the ATM technology as compared to both internet and mobile banking. This is shown in the Table 1. The respondents were asked about the performance of electronic banking channels with respect to the service quality dimensions. It was shown that most of the service quality dimensions with an exception of including all the banking needs in the option menu, convenience, acknowledgement by name and voice online are positively related with ATMs.

However, most of the service quality dimensions are negatively related with both mobile and internet banking. This is as shown in Table 2 .
Table 1: Latest electronic banking service used by customers

\begin{tabular}{llc}
\hline & Response (percentage) & \\
\cline { 2 - 3 } Types of technology & Yes & No \\
\hline used by customer & 90.7 & 9.3 \\
ATM banking & 28.0 & 72.0 \\
Mobile banking & 32.0 & 68.0 \\
Internet banking & &
\end{tabular}

Of the $75 \%$ customers interviewed, $77.3 \%$ of the respondents' preferred ATM method of cash withdrawal and $22.7 \%$ preferred using teller method. Of the 75 customer interviewed, $26.7 \%$ preferred using ATM method of cash deposit while $73.3 \%$ customers preferred using teller approach in depositing their cash.

Importance and performance of various factors considered in the electronic banking services. The respondents were asked to rate the importance and performance of various factors considered in the electronic banking services. The negative scores imply that given the importance of these items, their mean performance scores are problematic.

Table 3 shows that the respondents are not generally satisfied with their respective banks. This implies that there is an expectation gap i.e., there is a difference between what the customer expects and the actual services being delivered. This has a negative impact particularly on banks that rely on electronic systems to increase their customer base.

It could be argued that the performance of electronic banking services falls within the area considered equivalent to the respondents zone of tolerance. This suggests that even though the respondents perceive that the electronic banking services as not live up to expectations for what constitutes a quality service they are at least not dissatisfied with their bank's performance as long as certain conditions are met.

Conversely, expectations may have been low of banking provision generally. Other possible reasons include (perceived) difficulties in changing service provider and the experience of the customer i.e., the less experienced the customer is the lower the expectation of the service. The less new e-banking becomes the more experienced the customer will be.

The customer indicates that they are satisfied in the following areas operates $24 \mathrm{~h}$ a day have all banking needs included be capable of performing all transactions accurately being personalized e.g., greet me by name, provide secure services, acknowledged me by name, provide services in a number of different languages and provide voice online directions for new users. As indicated in Table 3 , be able to satisfy my complaints within $24 \mathrm{~h}$, be able to set up accounts so that I can perform transaction immediately, process my transactions effectively (so I do not need to wait), provide a customer friendly environment whilst waiting in the queue to be 
Int. Business Manage., 4 (4): 209-221, 2010

Table 2: Correlation matrix on electronic banking channel

\begin{tabular}{|c|c|c|c|}
\hline Service quality dimension & ATM & Mobile & Internet \\
\hline Ease use & 0.037 & 0.0350 & -0.0133 \\
\hline Operates $24 \mathrm{~h}$ a day & 0.036 & -0.0153 & -0.1790 \\
\hline All banking needs by menu option & -0.189 & -0.0220 & -0.1050 \\
\hline Process my transactions efficiently (not wait) & 0.168 & 0.0230 & -0.0620 \\
\hline Performs all transactions accurately & 0.123 & -0.1050 & -0.0460 \\
\hline Give you a written guarantee that transactions have taken place & 0.048 & -0.0930 & 0.0090 \\
\hline Provide accurate records & 0.126 & -0.1760 & -0.1120 \\
\hline Be personalized, e.g., greet you by name & 0.047 & -0.1640 & -0.2070 \\
\hline Have its ATMs conveniently located & -0.154 & -0.1290 & -0.9800 \\
\hline Provide secure services & 0.061 & -0.6000 & 0.4000 \\
\hline Special service to disabled & 0.111 & 0.1000 & 0.1550 \\
\hline Acknowledge me by name on the screen during the transaction & -0.109 & -0.1810 & -0.1450 \\
\hline Have a user-friendly system in place to make ATM transactions & 0.098 & 0.0120 & 0.2620 \\
\hline Connect you immediately to the service & 0.094 & 0.1130 & -0.2390 \\
\hline Provide voice/online directions for new users & -0.037 & -0.2410 & -0.2280 \\
\hline Provide a customer friendly environment whilst waiting in the queue to be served such as music & 0.128 & -0.1400 & -0.0160 \\
\hline $\begin{array}{l}\text { Provide a customer friendly environment whilst waiting in the queue to be served such as advertising } \\
\text { about other services the bank provides }\end{array}$ & 0.128 & -0.1270 & -0.0420 \\
\hline
\end{tabular}

Research data (2010)

Table 3: Sample response across items

\begin{tabular}{|c|c|c|c|}
\hline Attributes & mportance rating & Performance rating & Performance importance \\
\hline Internet banking: An idea electronic banking service should:ease use & 4.21 & 4.11 & -0.10 \\
\hline Operates $24 \mathrm{~h}$ a day & 4.15 & 4.38 & 0.23 \\
\hline All your banking needs in the menu options & 3.99 & 4.11 & 0.12 \\
\hline Process my transactions efficiently (not wait) & 4.47 & 4.08 & -0.39 \\
\hline Performs transactions immediately & 4.41 & 3.92 & -0.49 \\
\hline Performs all transactions accurately & 4.15 & 4.23 & 0.08 \\
\hline Give you a written guarantee that transactions have taken place & 3.98 & 3.85 & -.13 \\
\hline Provide accurate records & 4.33 & 4.24 & -0.09 \\
\hline Be personalized, e.g., greet you by name & 3.66 & 3.96 & 0.30 \\
\hline Be able to satisfy your complaints & 4.25 & 3.68 & -0.57 \\
\hline Provide customer feedback services & 4.06 & 3.81 & -0.25 \\
\hline ATM: An ideal electronic banking services should be: Have its ATMs conveniently located & 4.50 & 4.09 & -0.41 \\
\hline Provide secure services & 4.37 & 4.43 & 0.06 \\
\hline Acknowledge me by name on the screen during the transaction & 3.41 & 3.27 & -0.14 \\
\hline Have a user-friendly system in place to make ATM transactions easier & 4.22 & 4.11 & -0.11 \\
\hline Provide services in different languages & 3.97 & 4.02 & 0.05 \\
\hline Telephone Banking: an ideal electronic banking should:connect you immediately to the service & 3.97 & 3.77 & -0.20 \\
\hline Provide voice/online directions for new users & 3.55 & 3.68 & 0.13 \\
\hline Provide a customer friendly environment whilst waiting in the queue to be served such as music & 3.43 & 3.37 & -0.06 \\
\hline $\begin{array}{l}\text { Provide a customer friendly environment whilst waiting in the queue to be served such as } \\
\text { advertising about other services the bank provides }\end{array}$ & 3.45 & 3.07 & -0.38 \\
\hline
\end{tabular}

advertising about other services the bank provides

Research data (2010)

served such as advertising about other services the bank provides and provide customer feedback are amongst others regarded as important yet the needs are not being met.

This implies that customer's satisfaction levels can only be raised if the customer is fully confident that their transactions i.e., going to be dealt with as efficiently, diligently, friendly (advertising), provision of feedback and able to satisfy customer's complaints as they would be in a face to face service encounter.

The lack of physical presence or personnel does not lower banking customer's expectation levels with regards to service quality, in fact it may raise expectations levels of delivery, quality, trust and the need to build, maintain and consistently enhance relationships. The rank ordering of the different service dimensions will
Table 4: Ranking of service dimensions in terms of their importance

\begin{tabular}{lc}
\hline Service dimension & Percentage \\
\hline Secure services & 66.2 \\
Convenience & 63.5 \\
Efficiency & 61.6 \\
Performance of transactions & 54.8 \\
Accurate records & 54.8 \\
User friendly sy stem & 51.4 \\
Be able to satisfy complaints & 47.2 \\
Accurate transactions & 43.8 \\
Efficiency (overall) & 41.7 \\
Recognition & 41.1 \\
\hline
\end{tabular}

Research data (2010)

ensure clarity of the customer's perception of the respondents. The rank order according to Table 4 shows that $66.2 \%$ of the respondents indicated that secure services as the most important dimension followed by convenient location of ATMs, efficiency (not need to 
wait), ability to set up accounts so that I can perform transactions immediately, accuracy or records, user friendly, complaint satisfaction, accurate transactions, operation in $24 \mathrm{~h}$ and recognition.

\section{CONCLUSION}

The analysis from the importance- performance indicates that there is perceptual problem when the sample indicates poor performance of electronic banking facilities compared with an idea banking service. The introduction and growth of technology has been considered whilst acknowledging that providing a quality service is viewed as a key strategic factor in establishing competitive advantage. Due to this, research was carried out to establish relationship between technology and service quality in banking industry.

It was established that there is a direct relationship between technology and service quality in the banking industry. This was made possible through the use of correlation analysis, percentage and means. The use of technology in banking enhances the service offering to the customer.

However, the level of experience with electronic banking and level of education of the customer. For instance, expert banking customers tend to have higher expectations than their novice counterparts.

This expertise may relate to both financial and technological issues and banks need to be mindful of these customer differences when designing their service offerings. The key factors for satisfaction/dissatisfaction in the Nigerian banking industry in relation to technology was established. This was made possible through the use of importance/performance grid.

The e-banking customers seem to be quite satisfied in the following areas: security, efficiency, accurate records, convenience and accurate transactions. The importance performance grid shows that convenience, immediate performance of transactions and efficiency (no need to wait) lies in the concentrate quadrant. The respondents indicated that security and operation of the electronic banking lies in the keep up the good researchers quadrant.

Be personalized, provision of a customer friendly environment in terms of music and advertizing while on the process of getting the services and provision of services in a number of different languages lies in the low priority quadrant. Having all the banking needs included in the option menu and accurate performance of the transactions lies in the possible overkill quadrant.

\section{RECOMMENDATIONS}

The banking institutions should use the importance/performance grid as a strategic tool for the development of strategies as it gives a clear pictorial presentation of the factors that are critical for resource allocation. From the importance/performance grid, it is important that the financial institutions wanting customers to use and be satisfied with banking technology must implement personalized aspect to the service i.e., getting to understand what the customer needs and act as per the demand. The banks should pay special attention to convenience by providing the customers with electronic banking service at points which can easily be accessible.

For instance, some ATMs should be installed in supermarkets, learning institutions and medical centres. The banks' management should also improve their ATM systems so as to minimize waiting time in the queue. This will improve the efficiency in the service delivery hence boosts customer confidence. Banks should also provide customers with a toll free number. This could handle customers with complaints and general feedback about the electronic banking services. This would not only provide a service to a customer that is free but also provide the bank with valuable information for future development on electronic service.

The bank's management should revise their resource allocation in light of importance/performance findings. Having banking needs included in a option menu and accurate performance of the transactions lies in the possible overall quadrant which means that management thinks it is more important than customer do. The banks should provide statements for every transaction that has been conducted electronically.

This will enable customers to verify accuracy of all transactions including transaction confirmation. According to Lovelock (1991), customer feedback is an established concept of strategic planning. Therefore, it is recommended that performance of banking institutions should be monitored on a regular basis.

The researchers conducted a survey in the banking industry in Nigeria and recommends that a study should be carried out to determine the parameters of the customer's zone of zero tolerance. This will enable managers to understand at what point customers cease to be satisfied with core service they are receiving. The researchers also recommends that a study should be carried out to establish the challenges encountered by the customers in the process of using electronic banking in the service delivery. 


\section{REFERENCES}

Akinyele, S.T., 2007. Gender bias and customer satisfaction in the retail sector. Proceedings of 8 th Annual International Conference International Academy of Business and Development, May 29June 2, London Metropolitan University, Stapleton House, pp: 277-281.

Akinyele, S.T. and F.A. Akinyele, 2008. An evaluation of service quality: A critical review and measurement. J. Contemporary Manage., 2: 1-21.

Al-Hawari, M. and W. Tony, 2006. The effect of automated service quality on australian banks financial performance and the mediating role of customer satisfaction. Market. Int. Plann., 24: 127-147.

Barnes, S. and R. Vidgen, 2000. Webqual: An exploration of web site quality. Proceedings of the 8th European Conference on Information Systems, July 3, Vienna, pp: 2000-2000.

Bateson, J. and S. Hoffman, 1997. Measuring customer satisfaction and employee attitude at Forte Hotels. Mnaging Service Qual., 7: 290-291.

Bateson, J., 1985. Perceived Control and the Service Encounter. In: The Service Encounter Managing Employee/Customer Interaction in Service Businesses, Czepiel, J.A. (Ed.). Lexington Books, Lexington $\mathrm{MA}$

Bateson, J., 2000. The relationship among perceived quality, risk and product value. J. Prod. Brand Manage., 13: 156-167.

Bauer, H.H., M. Hammerschmidt and T. Falk, 2005. Measuring the quality of e-banking portals. Int. J. Bank Marketing, 23: 153-175.

Berry, L.L., A. Parasuraman and V.A. Zeithaml, 1994. Improving service quality in America: Lessons learned. Acad. Manage. Executive, 8: 32-52.

Berry, L., 1995. On Great Service: A Framework for Action. Free Press, New York.

Bitner, R., 2000. Technology infusion in service emcounters. J. Acad. Market. Sci., 28: 138-149.

Bitner, J.M., 2001. Service and technology: Opportunities and paradoxes. Managing Service Qual., 11: 375-379.

Boer, T., 2002. E-services: Operations strategy-A case study and a method for analyzing operational benefits. J. Operat. Manage., 20: 175-188.

Carman, J.M., 1990. Consumer perceptions of service quality an assessment of the SERVQUAL dimensions. J. Retail., 66: 33-55.

Chowdhary, N. and M. Prakash, 2007. Prioritizing service quality dimensions. Managing Service Qual., 17: 493-509.
Cox, J. and B.G.G. Dale, 2001. Service quality and ecommerce: An exploratory analysis. Managing Service Qual., 11: 121-131.

Cronin, J., 2003. Looking back to see forward in service marketing: Some ideas to consider. Managing Service Qual., 13: 332-337.

Crosby, H., 1979. Quality Phenomenon: The Conceptual Understanding of Quality in Face-to Face Service Encounters. In: The Service Encounter, Czepiel, J.A., M.R. Solomon and C.F. Surprenant (Eds.). Lexington Books, Lexington, MA.

Dabholkar, P. and R. Bagozzi, 2002. An attitudinal model of technology-based self service: Moderating effects of consumer's traits and situational factors. J. Acad. Market. Sci., 30: 184-201.

Dabholkar, P., 1994. Technology based service delivery. Adv. Services Manage., 3: 241-271.

Dabholkar, P.A., 2000. Technology in Service Delivery: Implications for Self-Service and Service e-Support. Sage Publications, Beverly Hills, CA.

Daniel, D., 1999. Service quality: Beyond cognitive assessment service Sweden. Managing Service Qual., 15: 127-131

Davis, F.D., R.P. Bagozzi and P.R. Warshaw, 1989. User acceptance of computer technology: A comparison of two theoretical models. Manage. Sci., 35: 982-1003.

Distri, B., 2003. Development of e-commerce sectors in the Arab region. Proceedings of the E Western Asia Preparatory Conference for the World Summit on the Information Society (WSIS), Beirut.

Doyle, T. and J. Melanson, 2001. B2B web exchanges: Easier hyped than done. J. Bus. Startegy, 22: 10-13.

Ennew, C., 1993. Personal financial service: Marketing strategy determination. Int. J. Bank Market., 7: 3-8.

Fengenbaum, M., 1995. The Service Profit Chain. Free Press, New York.

Goodman, F., P.P. Carlos and A. Henten, 1986. Service model and its marketing implications. Eur. J. Market., 18: $36-44$.

Gronroos, E., 2000. The net offer model: A case example from the virtual market place. Manage. Decision, 38: 243-252.

Gronroos, E., 2001. Service quality dimensions: An examination of gronroos service quality model. Managing Service Qual., 14: 266-277.

Gummeson, E., 1991. Qualitative Methods in Management Research. Sage Publications, New York.

Hawkins, J., 2001. The banking industry in the emerging market economies: Competition, consolidation and systemic stability: An overview. BIS Papers No. 4. pp: 1-44. http://folk.uio.no/gabrielm/ECON4420/ ECON4420-H03/BISpap04.pdf\#page $=7$. 
Igbal, S., 2003. Understanding consumer choices and preferences in transaction-based e-services. J. Service Res., 6: 51-65.

Joseph, M. and J. Beatriz, 1997. Service quality in education: A student perspective. Qual. Assurance Educ., 5: 15-21.

Joseph, M., C. McClure and B. Joseph, 1999. Service quality in the banking sector: The impact of technology on service delivery. Int. J. Bank Market., 17: 182-193.

Juran, K. and N. Gryana, 1988. Service quality: Guides for marketers. Managing Service Qual., 9: 337-351.

Kim, L., 2006. Online service attributes available on apparel retail websites: An E-S-QUAL approach. Managing Service Qual., 16: 51-77.

Lake, K. and J. Hickey, 2002. Service quality: A qualitative assessment. J. Market., 56: 55-68.

Lang, B. and M. Colgate, 2003. Relationship quality, online banking and the information technology gap. Int. J. Bank Market., 21: 29-37.

Lee, L. and H. Lin, 1996. A comparison of question scales used for measuring customer satisfaction. Int. J. Service Ind. Mnage., 7: 4-26.

Lehtinen, U. and J.R. Lehtinen, 1982. Service quality: A study of quality dimensions. Unpublished Working Paper, Service Management Institute, Helsinki, Finland.

Lewis, B. and V. Mitchell, 1994. Service quality: Student assessment of banks and societies. Int. J. Bank Market., 12: 3-12.

Lloyd-Walker, B. and Y. Cheung, 1998. IT to support service quality excellence in the Australian banking industry. Managing Service Qual., 8: 350-358.

Lovelock, C.H., 1991. Service Marketing. 2nd Edn., Prentice Hall International, New Jersey.

Martilia, J. and J. James, 1977. Importance-performance analysis. J. Marketing, 41: 77-79.

Mols, N.P., 1998. The behavioural consequences of PC banking. Int. J. Bank Market., 16: 195-201.

Mols, N., 2000. The internet and service marketing: The case of Danish retail banking. Internet Res., 10: 7-18.

Moon, Y. and F. Free, 2000. Exploding the self service myth. Harvard Bus. Rev., 78: 26-27.

Mugambi, D., 2006. A survey of internal service delivery systems in Nigeria commercial bank. M.Ba Thesis, University of Ilorin.

Nielsen, J.F., 2002. Internet technology and customer linking in Nordic banking. Int. J. Service Ind. Manage., 13: 475-495.

Oakland, J., 2000. Total Quality Management. Butterworth Heinemann, Oxford.

Ojunga, S., 2005. A survey of E-commerce in commercial banks in Nigeria. M.Ba Thesis, University of Ilorin.
Oliveira, C., 2002. Achieving competitive capabilities in eservices. Technol. Forecasting Social Change, 69: 721-739.

Onkvisit, S. and J.J. Shaw, 1991. Is services marketing really different. J. Professional Service Market., 7: 3-17.

Parasuraman, A. and C.L. Colby, 2001. Techno-Ready Marketing: How and Why Your Customers Adopt Technology. Free Press, New York.

Parasuraman, A., V.A. Zeithaml and L.L. Berry, 1985. A conceptual model of service quality and its implications for future research. J. Market., 49: 41-50.

Parasuraman, A., V. Liu and P.G. Klaus, 1995. Why improving quality doesn't improve quality. California Mnaage. Rev.

Parasuraman, A., V.A. Zeithaml and L.L. Berry, 1998. SERVQUAL: A multiple-item scale for measuring consumer perceptions. J. Retailing, 64: 12-40.

Peter, J. and U. Waterman, 1995. The perceived quality concept: A mistake. Managing Service Qual., 11: 150-152.

Regan, W.J., 1963. The service revolution. J. Marketing, 47: $57-62$.

Roth, A. and I. Menor, 2003. Insights into service operations management: A research agenda. Prod. Operat. Manage., 12: 145-164.

Rust, R.T. and K.N. Lemon, 2001. E-service and customer. Int. J. Electronic Commerce, 5: 85-101.

Saunders, W., 1994. Universal Banking in the United States. Wiley and Sons Inc., New York.

Schltze, U., 2003. Complementing self-service technology with service relationships: The customer perspective. E-Service J., 3: 7-31

Sethi, V. and W. King, 1994. Development of measures to assess the extent to which an information technology application provides advantage. Manage. Sci., 40: 1601-1627.

Smith, A.M., 1993. Quality aspects of services marketing. Marketing Intell. Plann., 8: 25-32.

Smith, C.P., 1987. Retail Banking Technology. IBC, London.

Tapiero, C., 1996. Service Management and Marketing. Lexington Books, Lexington, MA.

Turban, E., D. King, J. Lee, M. Warkentin and M. Chung, 2002. Electronic Commerce A Managerial Perspective. 2nd Edn., Pearson Education, New Jersey.

Vandermerwe, S., 1993. From tin Soldiers to Russian Dolls. Buterworth- Heinemann, Oxford.

Walker, N., 2002. Technology-enabled service delivery: An investigation of reasons affecting customer adoption and rejection. Int. J. Service Ind. Manage., 13: $91-106$. 
Weatherall, K., 1984. Oxford Textbook of Medicine. Oxford University Press, Oxford.

Yang Z., 2001. Consumer perceptions of service quality in internet-based electronic commerce. Proceedings of the EMAC Conference, May 8-11, Bergen, pp: 110-120.

Yang, Z. and X. Fang, 2004. Online service quality dimensions and their relationship with satisfaction: A content analysis of customer reviews of securities brokerage services. Int. J. Service Ind. Manage., 15: 302-326.

Yen, H.R., 2005. An attribute-based model of quality satisfaction for internet self service technology. Service Ind. J., 25: 641-659.

Zairi, A., 2003. Global benchmarking for internet and Ecommerce applications. http://www.brad.ac.uk/acad/ management/external/pdf/workingpapers/2003/Boo klet_03-12.pdf.
Zeitham1, V.A. and A. Bitner, 1996. Service management: A management focus for service competition. Int. J. Service Ind. Manage., 1: 6-14.

Zeithaml, V.A., 2000a. A conceptual framework of understanding e-service quality: Implications for future research and managerial practice. MSI Working Paper Series No. 00-115. http://www. msi.org/publications/publication.cfm?pub=17.

Zeitham1, V.A., 2000b. Service quality, profitability and the economic w orth of customers: What we know and what we need to learn. J. Acad. Market. Sci., 28: 67-85.

Zhang, P., 2000. The effects of animation on information seeking performance on the world wide web: Securing attention of interfering with primary tasks? J. Association Inform. Syst., 1: 1-28.

Zhang, X. and V.R. Prybutok, 2005. A consumer perspective of e-service quality. IEEE Tran. Eng. Manage., 52: 461-477. 